\title{
Computed Tomography Perfusion Imaging
}

National Cancer Institute

\section{Source}

National Cancer Institute. Computed Tomography Perfusion Imaging. NCI Thesaurus.

Code C116442.

An application of CT imaging used to assess the quality of blood flow to an organ or tissue. 